\title{
Industrial Location in Developing Countries
}

Uwe Deichmann, Somik V. Lall, Stephen J. Redding, and Anthony J. Venables

Despite a diminishing role in industrial countries, the manufacturing sector continues to be an engine of economic growth in most developing countries. This article surveys the evidence on the determinants of industry location in developing countries. It also employs micro data for India and Indonesia to illustrate recent spatial dynamics of manufacturing relocation within urban agglomerations. Both theory and empirical evidence suggest that agglomeration benefits, market access, and infrastructure endowments in large cities outweigh the costs of congestion, higher wages, and land prices. Despite this evidence, many countries have tried to encourage industrial firms to locate in secondary cities or other lagging areas. Cross-country evidence suggests that fiscal incentives to do so rarely succeed. They appear to influence business location decisions among comparable locations, but the result may be a negative-sum game between regions and inefficiently low tax rates, which prevent public goods from being funded at sufficiently high levels. Relocation tends to be within and between agglomerations rather than from large cities to smaller cities or lagging regions. Rather than provide subsidies and tax breaks, policymakers should focus on streamlining laws and regulations to make the business environment more attractive. JEL codes: O18, R12, R38

Modern sector activity in developing countries exhibits pronounced spatial clustering. This occurs at different scales, ranging from the extreme specialization of some small towns in particular products to the dominance of primate cities in many countries. Identifying the causes and consequences of this concentrationand possible policies for dealing with it - can be done in several ways. One is to look at the benefits and costs of cities as a whole, investigating the determinants of city structure and urban performance (see Overman and Venables 2005 for a review). Another is to look at migration flows, a subject that has received a good deal of attention in the development literature (Lall, Selod, and Shalizi 2006).

(C) The Author 2008. Published by Oxford University Press on behalf of the International Bank for Reconstruction and Development / THE WORLD BANK. All rights reserved. For permissions, please e-mail: journals.permissions@oxfordjournals.org doi;10.1093/wbro/lkn007 Advance Access publication May 27, 2008 
A third way-the focus of this article-is to identify the determinants of the location of modern sector activity. Academic research seeks to understand how the characteristics of a location enhance firm-level productivity and how industrialization interacts with urbanization. While cross-country data can provide some insights into these issues, empirical research increasingly uses micro-data on firms to study the concentration and deconcentration of industrial activity.

These research questions are motivated by considerable policy interest in the determinants of industry location. City or regional managers want to attract domestic or foreign firms that bring employment and tax revenue. Provincial and national policymakers are concerned with overall urbanization patterns and the spatial distribution of economic activities across the country. A primary concern is that a high concentration of industries triggers what is often perceived as excessive urbanization in some areas and limited growth and economic opportunities in others. Policy interventions try to stimulate growth in secondary cities or lagging regions by steering industries away from large, established urban centers.

For both local and national policy formulations, it is necessary to determine the types of incentives and public investments that influence firm location. What complicates policymaking is the inherent tradeoff between efficiency and equity in intervening in market-driven concentration processes. Firms locate in already dense urban areas because they realize tangible benefits from being close to other firms and to consumers, thick labor markets, export hubs, governments, and regulators. Employment opportunities in these centers attracts migrants from other regions, increasing urban growth and demand for services. Local policies need to focus on managing growth through appropriate public investments.

Social and political factors put pressure on policymakers to move jobs to smaller towns and lagging regions, particularly in countries with geographically proportional political representation. Firms locate in these regions only if infrastructure investments or other incentives compensate for forgoing the agglomeration benefits of big cities. In the final analysis, the decision to invest public funds to influence private sector location decisions is political and depends on a country's priorities and available resources. In most cases these decisions are made with little explicit awareness of their full costs and benefits. Understanding these tradeoffs is therefore a high priority in light of rapid industrialization and urbanization in developing countries.

This article is organized as follows. Section I outlines some basic facts about growth, urbanization, and structural change. Section II surveys the forces that shape the location decisions of firms. It briefly outlines the theory and then reviews empirical studies of factors that determine location, noting that agglomeration forces, market access, and infrastructure provision all inhibit dispersion of activity. Section III turns to policy, reviewing the instruments countries have used to influence the relocation of industry to achieve regional development 
objectives. Badly designed regulation and ill-conceived infrastructure investments can have strong negative effects. Fiscal incentives may sometimes lead to relocation between similar regions, but they are rarely sufficient to induce firms to move from productive urban agglomerations to lagging regions.

Section IV includes micro-data from India and Indonesia and sheds light on where modern sector activity is concentrated within the urban hierarchy and how this has changed over time. Despite large differences in geography and institutions, the two countries display a common pattern of deconcentration toward peri-metropolitan areas on the fringes of the largest cities and toward large secondary cities. This pattern suggests that as industrialization proceeds, it is the areas on the edge of existing urban agglomerations and in the next tier of cities that are likely to experience the most rapid growth. Understanding these patterns of urban development can help identify future infrastructure priorities and development bottlenecks.

The article focusses on formal-sector manufacturing, partly because of data availability. Services and other modern sector activities often represent a larger share of the workforce, even in most developing countries; it would clearly be desirable to have a better view of the role of the informal sector. However, considerable evidence suggests that manufacturing activity, income growth, and poverty reduction are linked. Research in India, for example, indicates that states that experienced rapid structural change also experienced more rapid rural and urban poverty reduction (Burgess and Venables 2004). This link highlights the critical role of labor-intensive manufacturing in enabling countries and regions to transition from low- to middle-income status (Collier 2007).

\section{Economic Structure, Urbanization, and Income}

How does urbanization vary with development? To what extent are differences in this relationship driven by manufacturing and other modern sector activities? How do these patterns correlate with income levels?

Manufacturing and per capita income have a nonlinear relation (figure 1). The manufacturing sector tends to grow up to some level as countries develop, after which it remains stable or diminishes in importance.

Ideally, what is wanted is a measure of modern sector activity, but manufacturing is a poor proxy for this. Instead, the share of agriculture is examined. Successful economies would be expected to undergo a greater structural transformation from agriculture to manufacturing than less successful economies. The correlation between per capita income and the importance of agriculture in the national economy is strongly negative (figure 2 ). 
Figure 1. Manufacturing and per Capita Income, 2000

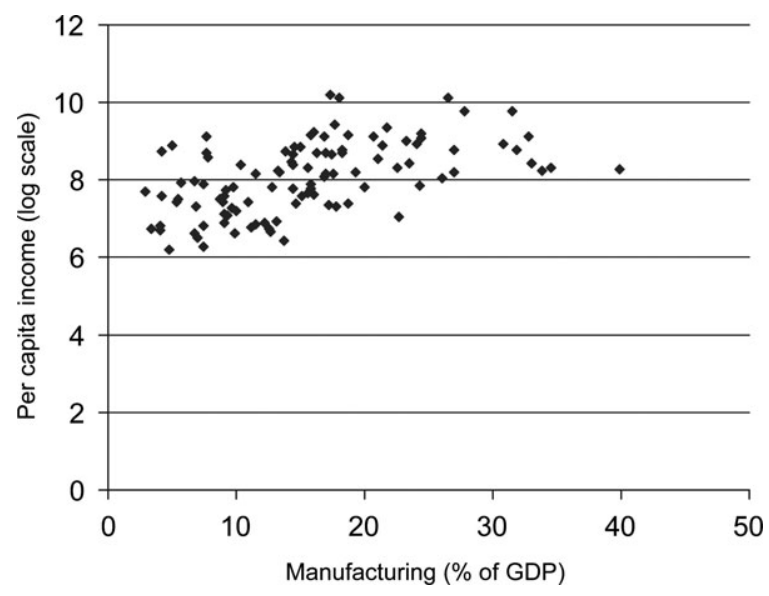

Source: World Bank (2005).

Figures 1 and 2 show the situation in 2000. Looking instead at changes over the period 1980-2000 shows a significant positive correlation between the increase in the share of manufacturing and the decline in the share of agriculture on the one hand and the growth of per capita income on the other. This relation indicates that, on average, successful economies experienced greater structural change from agriculture to industry than less successful economies.

Figure 2. Agriculture and per Capita Income 2000

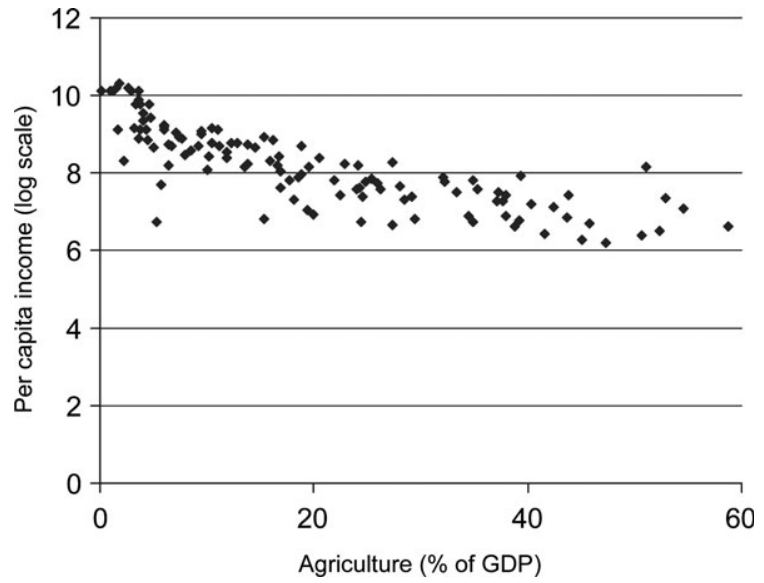


The relation between manufacturing and urbanization shows a positive, albeit weak, correlation across countries. Once again, modern sector activities other than manufacturing are important, and the negative correlation between agriculture and urbanization is much stronger than the positive relation with manufacturing. The relation is also stronger in changes: increasing manufacturing shares in income and increasing urban shares in population were positively associated over 1980-2000.

Finally, the relation between urbanization and per capita income is strongly positive (figure 3). For the poorest and the richest groups of countries, there is no association between the change in urbanization and the change in per capita income between 1980 and 2000. In contrast, among the middle range of countries the association is significant.

A substantial body of literature looks at urban structure. Henderson (2000) finds that national urban primacy (the dominance of the largest city) rises with growth from low income levels, peaks at low-to-middle levels (1987 per capita purchasing power parity of about $\$ 2,500$ ), and declines thereafter. This finding is consistent with that of Williamson (1965) and Shishido and Wheaton (1982), who find that spatial inequalities first increase and then decrease with the level of development.

Are high urban primacy rates in developing countries a temporary phenomenon, or are they structural? Historical evidence provides some indication. Today's industrial countries tend to have a more balanced urban system than most developing nations. Data on urban growth in the nineteenth century suggest that today's industrial countries did not go through a similar phase of very rapid and highly concentrated urbanization (Bairoch 1988).

Figure 3. Urbanization and per Capita Income 2000

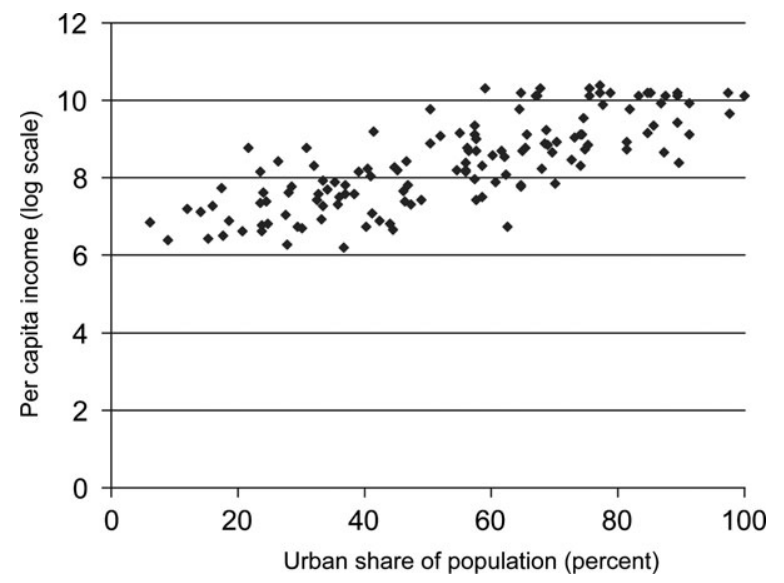

Source: World Bank (2005). 
Puga (1998) attributes these differences largely to two factors. First, transport costs were higher during European urbanization, and agglomeration benefits were therefore lower. Industrial development, and consequently migration, were therefore distributed over a larger set of urban areas. Second, the pool of agricultural workers that could potentially migrate to cities has been larger in developing countries than it was in Europe in the nineteenth century. Population growth in today's developing countries has tended to outpace the expansion of agricultural land, so that the quantity of land available per farmer is much smaller, increasing pressure to migrate. This in turn means that large rural-urban migration flows have not significantly reduced rural-urban wage differentials. Larger cities, which offer the highest returns, have therefore grown more rapidly than smaller ones. If, as happened in Europe, urban migration reduced wage differentials, smaller cities, even those that serve predominantly the agricultural hinterland, would be able to attract migrants.

Henderson $(2000,2002)$ reviews other likely reasons for the persistence of high primacy in developing countries. He notes that critical infrastructure is scarce and tends to be concentrated in the main metropolis of poorer countries. More generally, cross-country findings and historical experiences suggest that while manufacturing growth tends to raise per capita income, it is also associated with increasing urbanization and possibly with increasing spatial inequality.

\section{Determinants of Industrial Location}

The theory of industrial location is based on the relative profitability of activities in different locations, which depends on the prices and quality of inputs, the prices of outputs, and the efficiency of technology. Empirical studies of factors that determine location note that agglomeration forces, market access, and infrastructure provision all inhibit dispersion of activity.

\section{Theory}

The effects of higher wages, electricity, or land prices are qualitatively clear, although their magnitude varies empirically. Spatial variation in the revenue firms receive in selling their output is determined by access to markets (market size and transport infrastructure quality) and by competition from other suppliers. Locations from which large markets can be reached easily will be attractive for firms.

In standard models of firm location, good market access has a magnified effect on location decisions. Better market access of a location causes a greater than proportionate increase in the number of firms that choose to produce there, because firms prefer to locate in the larger market and export to smaller markets 
(bearing transport costs) rather than vice versa. This dynamic tends to lead production to be more spatially concentrated than the population as a whole. The relative strength of these effects varies across sectors, so that in equilibrium (when labor costs may be higher in large centers), one would expect to see some sectors locating close to large markets and others being dispersed as firms choose locations with lower wages. This theoretical prediction has substantial empirical support (see Davis and Weinstein 2003).

Other effects will further amplify the tendency of some sectors to cluster. In addition to locating close to consumers, firms may gain from proximity to other firms in their own or related sectors. Three sorts of mechanisms drive these effects. One is forward and backward linkages between firms. Firms that produce intermediate goods tend to locate close to their consumers, the downstream firms that buy their products (a demand, or backward, linkage). Downstream firms gain from locating close to their suppliers (a cost, or forward, linkage). There will therefore be a tendency for such activities to locate near one another.

A second clustering mechanism arises from the advantages of being in a thick labor market. If specialist skills are required, workers' incentives to acquire these skills are greatest in a location in which there are many firms. Conversely, firms' ability to hire specialist workers is greatest in a location with many such workers. Thick labor markets also reduce the vulnerability of firms and workers to adverse shocks and improve the quality of matches between specialized workers and firms looking for particular labor skills.

Finally, clustering can have direct productivity effects. Knowledge spillovers, as firms in a location learn best-practice techniques by observing other firms, raise overall productivity. As firms observe the success of other nearby firms performing a specific activity, they may copy its practices (Rodrik 2004).

Each of these clustering mechanisms may operate over different spatial and sectoral ranges. Linkages, labor skills, and learning effects, for example, may all be highly sector specific, in which case "localization" of particular industries would be expected. Towns and cities become highly specialized, creating garment centers, software centers, financial services centers, and so forth. Other sectors may benefit from a large market and from urban diversity as a source of complementary inputs, knowledge spillovers, and productivity benefits. These are forces for "urbanization" economies, as firms benefit from urban scale as a whole rather than from concentration of their own sector.

Opposing these tendencies to cluster are dispersion forces in the form of agglomeration costs. Large cities typically have high prices for immobile factors (land and housing), high commuting costs and congestion, and pollution diseconomies. Wages need to be high to compensate workers for these costs. A more dispersed pattern of firms would therefore be expected in sectors in which wage costs are important and clustering benefits relatively unimportant. Sectors in 
which agglomeration benefits exceed the higher costs of production will be concentrated in major urban centers.

The clustering of activities has major implications for the way in which economists think about development. A "neoclassical" view of the world suggests that underlying economic forces will tend to generate relatively smooth convergence of per capita incomes as capital and technology flow to low-cost locations. Large differences in the endowments of skills and institutions are predicted to converge over time. Locations are assumed to grow in parallel, with more rapidly growing lagging regions eventually catching up to dynamic ones.

By contrast, the presence of clustering and agglomeration forces suggests that growth may be sequential rather than parallel. Internationally, there is a rich club and a poor club, with relatively rapid, but sequential, transit of some countries from one club to the other. Within countries there are regional disparities, as some cities and regions benefit from cumulative causation processes while others are left out. These regionally uneven outcomes make it important to understand the tradeoffs between wages, infrastructure, regulation, and agglomeration forces in shaping the location of industry in developing countries.

\section{Evidence}

The relative importance of different factors in influencing the location decisions of firms can be identified in several ways. One is to ask firms directly, as investment climate surveys typically do. Such surveys gather responses from firm representatives on aspects of the business environment, including the quality of utilities, other infrastructure, and the regulatory environment that affects their firm's operations. The quality of transport infrastructure can be captured by road density or distance from a container port. Indicators of the regulatory environment include the time taken to start a new business, the procedures for hiring and laying off employees, and the level of corruption among officials. These measures, which enable areas to benchmark their performance, become inputs into broader analysis.

Investment climate surveys include subjective information about barriers to doing business. These perceptions often vary widely across regions. For example, infrastructure was identified as a "major or severe obstacle" by 61 percent of businesses surveyed in the southern Indian state of Karnataka but by less than 5 percent of businesses in Delhi (World Bank 2004). Interpretation of these subjective responses can be difficult, because they are influenced by the needs and expectations of local businesses. The cost of regulation, for example, is often perceived as higher in areas that, according to objective criteria, have better business environments (World Bank 2004).

A second source of evidence on the determinants of firm location decisions is econometric analysis of empirical patterns. A typical study of plant location might 
estimate the probability that firm $i$ in sector $k$ will locate in region $j$ based on explanatory variables that describe local production costs as well as barriers and opportunities across potential locations. (For a formal statement of such a model and a discussion of the econometric issues, see, for example, Deichmann and others 2005.)

Several studies have been conducted on firm location decisions (table 1 ). ${ }^{1}$ The findings of this literature are summarized below.

Factor prices. Wage levels should have a negative impact on location decisions by firms, once other factors are controlled for. The empirical findings on this relation are mixed. Lall and Mengistae (2005) find that cross-city wage variation in India has a strongly negative effect on activity in high-technology sectors but no effect in low-technology sectors. For Indonesia, the evidence is also mixed (Henderson, Kuncoro, and Nasution 1996; Deichmann and others 2005). The likely reason for these mixed results is the difficulty of empirically controlling for the skill composition of each firm's labor force, given the aggregate-level information typically available.

Utility services. One of the most robust findings is the importance of the quality and, to a lesser extent, the price of service provision, in particular electricity. Using the proportion of firms that have their own generators (a proxy for unreliable electricity supply), Lall and Mengistae (2005) find a significant negative effect in India. Mani, Pargal, and Huq (1997) find negative effects of state-level power shortages and of high energy prices in India. Rud (2005) shows that state regulation of electricity influences firms' incentives to vertically integrate and affects their measured productivity, in part because of the need to produce their own power.

Market access and international trade. Economic liberalization and opening to trade provide a natural experiment with which to assess location forces. Studies indicate two forces at work. Firms want proximity to ports as well as the benefits of established centers. Lall and Chakravorty (2005) examine the location of private sector investments following liberalization of the Indian economy. Once regulations were relaxed, private sector investment tended to favor industrial clusters and metropolitan centers with access to the coast. This suggests historical path dependence, as firms seek out existing agglomerations to remain competitive in a more open economy. In some cases local government policies act as a deterrent to locating a business in a particular location. Lall and Mengistae (2005) address the infrastructure issue by using proximity to international ports to measure international market access for cities in India. They find that it has a positive and highly significant impact on location decisions. 


\begin{tabular}{|c|c|c|c|c|c|c|c|c|}
\hline Location/study & Data & Factor prices & $\begin{array}{l}\text { Labor and } \\
\text { regulation }\end{array}$ & $\begin{array}{l}\text { Electricity } \\
\text { quality }\end{array}$ & Incentives & $\begin{array}{c}\text { Market access/ transport } \\
\text { infrastructure }\end{array}$ & $\begin{array}{l}\text { Firms in } \\
\text { supplier } \\
\text { industry }\end{array}$ & $\begin{array}{l}\text { Firms in own } \\
\quad \text { industry }\end{array}$ \\
\hline \multicolumn{9}{|l|}{ China } \\
\hline $\begin{array}{l}\text { Head and Ries } \\
\text { (1996) }\end{array}$ & $\begin{array}{l}\text { Foreign investments in } \\
54 \text { Chinese cities }\end{array}$ & No effect & - & Positive & $\begin{array}{l}\text { Very } \\
\text { positive }\end{array}$ & $\begin{array}{l}\text { Very positive for } \\
\text { railways and ports }\end{array}$ & Very positive & - \\
\hline $\begin{array}{l}\text { Amiti and Javorcik } \\
(2005)\end{array}$ & Foreign investments & - & - & - & - & $\begin{array}{l}\text { Positive; interprovincial } \\
\text { trade barriers deter } \\
\text { investment }\end{array}$ & Very positive & Very positive \\
\hline \multicolumn{9}{|l|}{ India } \\
\hline $\begin{array}{l}\text { Lall and Mengistae } \\
\text { (2005) }\end{array}$ & $\begin{array}{l}\text { Firm data on } 40 \text { cities } \\
\text { in } 8 \text { manufacturing } \\
\text { sectors }\end{array}$ & $\begin{array}{l}\text { Negative for } \\
\text { some } \\
\text { industries }\end{array}$ & Negative & Positive & Positive & Positive & - & Positive \\
\hline $\begin{array}{l}\text { Lall and } \\
\text { Chakravorty } \\
(2005)\end{array}$ & Firm investments & - & Negative & - & - & Positive & - & - \\
\hline $\begin{array}{l}\text { Mani, Pargal, and } \\
\text { Huq (1997) }\end{array}$ & $\begin{array}{l}418 \text { investment } \\
\text { projects in } 14 \text { states }\end{array}$ & $\begin{array}{l}\text { Positive for } \\
\text { some } \\
\text { industries }\end{array}$ & Negative & Positive & - & - & - & - \\
\hline \multicolumn{9}{|l|}{ Indonesia } \\
\hline $\begin{array}{l}\text { Deichmann and } \\
\text { others (2005) }\end{array}$ & $\begin{array}{l}\text { Firm data from } 294 \\
\text { districts in } 15 \\
\text { industries }\end{array}$ & $\begin{array}{l}\text { Negative for } \\
\text { most } \\
\text { industries }\end{array}$ & $\begin{array}{l}\text { Negative for } \\
\text { some } \\
\text { industries }\end{array}$ & & & $\begin{array}{l}\text { Positive for some } \\
\text { industries }\end{array}$ & $\begin{array}{l}\text { Positive for } \\
\text { some } \\
\text { industries }\end{array}$ & $\begin{array}{l}\text { Positive for } \\
\text { most } \\
\text { industries }\end{array}$ \\
\hline $\begin{array}{l}\text { Henderson, } \\
\text { Kuncoro, and } \\
\text { Nasution (1996) } \\
\end{array}$ & $\begin{array}{l}\text { Firm data on nonfood } \\
\text { manufacturing } \\
\text { kabupaten }\end{array}$ & Negative & - & Positive & - & $\begin{array}{l}\text { Positive (proximity to } \\
\text { metropolitan area) }\end{array}$ & - & Positive \\
\hline
\end{tabular}


Similarly, Head and Ries (1996) show that after implementation of an open door policy in China in 1978, foreign firms preferred to locate in cities with large industrial bases and a history of foreign investment. These cities, such as Shanghai and Shenzen, are also the main export hubs for China's manufacturing sector. The econometric work by Head and Ries controls for factors such as fiscal incentives and infrastructure, which make some regions more attractive than others.

In another study of China, Cheng (2007) shows the positive impact of existing Japanese firms on greenfield development by Japanese firms as well as the importance of high-quality support services. Lack of skilled labor and concentrations of state-owned enterprises discourage such investment.

The Mexican experience diverges from these trends, because trade with the United States pulls activity away from the traditional center of Mexico City toward northern agglomerations, such as Ciudad Juarez, Monterrey, and Tijuana. The border states increased their share of manufacturing employment from 21.0 percent in 1980 to 29.8 percent in 1993; over the same period Mexico City's share declined from 44.4 percent to 28.7 percent (Hanson 2005). The decline followed the opening of the Mexican economy to foreign trade and investment. A significant share of new establishments in the border states are branch plants of foreign corporations that take advantage of low wages and proximity to the U.S. market.

In both China and Mexico the focus of firm location decisions on regions that facilitate exports of manufacturing goods has led to increasing regional disparities of economic activity and, consequently, of welfare outcomes at the household level. In Mexico, for instance, there has been little expansion of economic activity in the south, and indicators of spatial inequality increased during the period of economic expansion in the north (Deichmann and others 2004).

Infrastructure and lagging regions. A longstanding question is whether infrastructure improvements-particularly improvements to transport infrastructureencourage firms to move to lagging regions. The theory is ambiguous, because infrastructure improves access for both exports from and imports to lagging regions. Empirical studies indicate that policy has succeeded in moving firms to second-level locations but not to lagging regions.

Deichmann and others (2005) investigate the issue for Indonesia. They estimate a location choice model to illustrate the potential effects of transport improvements on the relocation of firms, particularly to the lagging eastern part of the country. They also simulate the effects of an upgrading of road densities in peripheral eastern Indonesia to a level similar to that of the country's major agglomeration, Jakarta. They find that there is some relocation of firms in transport-sensitive sectors but that it occurs only from major agglomerations to other large cities with similar amenities (such as Surabaya), not to the more peripheral parts of the country. This evidence suggests that without other forms 
of public service provision and amenity creation, large-scale transport improvements are not sufficient to induce firms to relocate from agglomerations to peripheral areas.

Infrastructure links may enhance productivity and, combined with complementary investments, attract firms to lagging regions. But such investments can also have unintended consequences. Interregional transport improvements provide local firms with better access to the inputs and markets of more developed areas, but they also allow larger firms based in agglomerations to expand into laggingregion markets in competition with local producers. The higher transport costs of external producers are often more than made up for by economies of scale, better know-how, and lower overall unit cost of production. ${ }^{2}$

Clustering effects. Considerable evidence suggests that clustering forces are powerful determinants of firms' location decisions. A number of studies have sought to identify the sources of such effects, which include localization effects, suppliercustomer linkages, and urbanization effects.

Using firm-level survey data from India, Lall and Mengistae (2005) find that localization economies, as measured by own-industry concentration, have significant bearing on firm location decisions across cities. This effect is highest for technology-intensive sectors. Deichmann and others (2005) find similar evidence for manufacturing firms in Indonesia. Localization effects are more important for high-technology firms (such as office computing) and natural resource-based industries (such as wood or rubber and plastic). They are less important for footloose industries, such as garments and textiles. While industry concentration provides many benefits, some of them can be offset by rising wages, land rents, and higher transport costs caused by congestion. The net benefits of own-industry concentration therefore vary across sectors and may be marginal for sectors with low-skilled labor and standardized technologies.

A similar picture emerges in the Republic of Korea. Henderson, Lee, and Lee (2001) estimate scale economies using city-level industry data for 1983, 1989, and 1991-93. They find localization economies of up to 8 percent, with more modest economies in sectors that use predominantly standardized technologies and low-skilled workers.

The second major type of benefits due to clustering stems from the close proximity to buyers and suppliers in own or related industries. Location models in Deichmann and others (2005) find that access to suppliers influences location decisions of firms in several industries (food and beverages, garments, chemicals, rubber). In contrast, firm profit models estimated by Lall, Funderburg, and Yepes (2004) for Brazil and Lall and Chakravorty (2005) for India do not find significant gains from supplier access after controlling for market access and other sources of agglomeration economies. Amiti and Cameron (2004) show that 
externalities that arise from interindustry linkages are highly localized and have significant impacts on manufacturing performance (measured by wages) in Indonesia. Amiti and Javorcik (2005) find that market and supplier access in the province of entry are the most important factors affecting foreign entry in China. This finding is consistent with market fragmentation caused by underdeveloped transport infrastructure and informal trade barriers.

The third type of clustering is based on urbanization economies. Empirical studies by Bostic (1997) and Garcia-Mila and McGuire (1993) show that diversity in economic activity is positively associated with regional economic growth. Their finding confirms that of earlier empirical work examining the contribution of urbanization economies to productivity. Using U.S. manufacturing data at the two-digit Standard Industrial Classifications (SIC) level, Sveikauskas (1975) finds that a doubling of city size increases labor productivity 6 percent. Using Japanese data, Tabuchi (1986) finds that a doubling of population density increases labor productivity 4.3 percent.

The results from empirical studies on the relative importance of specialization and diversity are mixed. Glaeser and others (1992) find evidence only in favor of diversity. In contrast, Mirachy (1995) finds little evidence to support the diversity argument. Lall, Funderburg, and Yepes (2004) find evidence that diversity is the most important source of external cost reduction for Indian manufacturing establishments. Henderson, Kuncoro, and Turner (1995) show that in Indonesia the relative importance depends on the choice of industry. They find evidence of specialization externalities in mature capital goods industries and of diversity externalities in new high-tech industries. Their findings are consistent with product cycle theory (Vernon 1966), which predicts that new industries tend to prosper in large and diverse urban area but that with maturity their production facilities move to smaller and more-specialized cities. Localization economies, input-output linkages, and urbanization economies are not mutually exclusive. They may occur individually or in combination.

Regulation. Various measures of regulation are included in studies of firm location. Using the frequency of visits by government inspectors to plants in each industry and district as an indicator of enforcement, Lall and Mengistae (2005) find that predatory enforcement of business regulations has a significant negative effect on the attractiveness of Indian cities for employment in all broad sectors. Mani, Pargal, and Huq (1997) use Indian data to focus on environmental regulation and consider measures of the stringency of enforcement across states. Controlling for other variables, they find that the enforcement of environmental regulation has no effect on industrial location.

Probably the heaviest regulatory burden comes from employment legislation. Besley and Burgess (2004) find that pro-worker labor regulations in Indian states 
are associated with lower output, employment, investment, and productivity in registered or formal manufacturing but higher output in informal manufacturing. In a survey of 1,000 manufacturing establishments in 10 Indian states, managers indicated that they would reduce their work force by 16-17 percent if labor markets were more flexible (Dollar, Iarossi, and Mengistae 2001). Such a reduction would increase labor productivity and contribute to economic growth.

\section{The Role of Policy: Public Capital and Fiscal Incentives}

Countries have used a variety of instruments to influence the relocation of industry to achieve regional development objectives. Most important among these instruments are the provision of public infrastructure, and tax reductions, subsidies, and other incentives that attract firms to lagging regions.

Research on the links between infrastructure and economic growth dates back to Hirschman's (1958) work on theories of unbalanced growth and to other development theories on the role of economic and social overhead capital in national and regional development (Rosenstein-Rodan 1943; Nurske 1953; Nadiri 1970). Renewed interest over the past 15 years is based on numerous econometric studies estimating aggregate production functions in which infrastructure enters as an input. Aschauer's (1989) study of the United States and Biehl's (1986) study of the European Union were among the first to use this approach. Both suggest that infrastructure investments have important effects on productivity and growth.

This conclusion sparked debate on the possible effects of reducing infrastructure investments on productivity in the United States and other developed countries. Morrison and Schwartz (1996) and Nadiri and Mamuneas (1991) find that infrastructure provision in the United States yields cost savings to firms. Deno (1988) finds positive effects of infrastructure on the profits of manufacturing firms in 36 metropolitan areas. Panel estimates of a translog cost function for 11 states in the Federal Republic of Germany for 1970-88 show that public capital formation encouraged private investment (Seitz and Licht 1992) and contributed to cost savings (Conrad and Seitz 1992). Data from Spain for 1964-91 confirm that public capital (roads, water infrastructure, ports, and urban structures) had a significant positive effect on value added (the estimated elasticity is 8 percent ). The data also show that the effects of infrastructure on growth have diminished over time (Mas and others 1995). Evidence from developing countries based on similar analytical techniques is limited, largely because of the lack of reliable data on public capital stocks over time.

A drawback of production function-based studies is that it is difficult to identify the direction of causality between infrastructure investments and 
economic growth. Did infrastructure lead to economic growth, or did rapidly growing regions invest in infrastructure? Infrastructure investments are driven by regional and interregional demand, construction costs, financing possibilities, and explicit regional policies. Failure to consider what drives infrastructure investment will bias upward estimates of infrastructure's contribution to growth. Furthermore, the effect of infrastructure investment on economic development (or vice versa) may occur simultaneously, there may be time lags in the effect of one on the other, or the effect may be anticipatory. The public sector may expand infrastructure investment to accommodate dynamic economic growth in particular regions, or it may respond to severe bottlenecks or invest in regional infrastructure in anticipation of future demand (Rietveld and Boonstra 1995; de la Fuente 2000). It is thus very important to consider both the feedback relation between investments and economic growth and the timing of the effects in quantifying infrastructure's contribution to economic performance.

\section{Use of Fiscal Incentives}

Fiscal incentives have been widely used to attract industries and stimulate the growth potential of lagging regions. The rationale for doing so is that to attract firms, lagging regions need to offset the costs associated with transport and logistics, weaker infrastructure, higher factor prices, and lower levels of public services and amenities.

The evidence on the impacts of fiscal incentives is mixed: there is no conclusive evidence to suggest that these policies have succeeded in transforming the fortunes of lagging regions. Direct grants have only limited influence on location decisions if they are not large enough to offset localization benefits in existing agglomerations (Devereux, Griffith, and Simpson 2007). Agglomeration economies make firms less sensitive to differentials in tax rates. Cities such as New York and São Paulo, for example, can tax firms more heavily than cities such as Bloomington, Indiana, or Natal, Rio Grande do Norte, as the following country cases illustrate.

Brazil has a long history of policies aimed at reducing the large economic disparities between the northeast and the rest of the country (World Bank 1987). The goal has been to attract "dynamic" industries by providing fiscal incentives, fiscal transfers, and direct investments in infrastructure and developed land. In recent years expenditures have reached $\$ 3-\$ 4$ billion a year, much of it in the form of "constitutional funds"(funds created in 1989 to finance economic activities in the North and Northeast regions).

Evaluations of aggregate outcomes, such as changes in GDP per capita, suggest limited impacts (Ferreira 2004). Carvalho, Lall, and Timmins (2006) evaluate the effect of these incentives on firm entry in the targeted regions. They find that the 
allocation of constitutional funds did induce the entry of manufacturing establishments into lagging regions but that the effect was strongly conditioned on close proximity to firm headquarters.

Industrial development in the Republic of Korea has historically been concentrated around the large agglomerations of Seoul and Pusan. In an attempt to promote balanced regional growth and divert growth away from Seoul, the Korean government initiated large-scale programs in the 1960s and 1970s. Considerable resources were redistributed from major cities to less developed provinces in the form of block grants and other transfers.

Seoul, Pusan, Taegu, and Inchon generated the bulk of internal taxes in Korea, with Seoul accounting for about half of national internal taxes in 1983. Under the Local Share Tax Law of 1963, 13.2 percent of domestic taxes are annually earmarked for block grants, with each city's allocation based on the difference between its own revenues and its estimated needs based on standardized service provision assumptions. As a consequence of these policies, the dominance of Seoul and Pusan declined in the 1970s and 1980s, but growth continued just outside the boundaries of Seoul and Pusan and in a range of small and mediumsize cities strung along the already developed Seoul-Pusan axis (World Bank 1986; Murray 1988). The goal of moving firms from the country's large agglomerations to less developed provinces was thus not achieved.

The Mexican government has historically used fiscal incentives to promote industrial development outside the three largest urban agglomerations of the Mexico City Metropolitan Area, Guadalajara, and Monterrey. Between 1970 and 1980 industries locating outside these three large cities were eligible for a 50100 percent reduction in import duties and income, sales, and capital gains taxes, as well as accelerated depreciation and lower interest rates. Reviews of the program (World Bank 1977; Scott 1982) show that the impact on decentralization was either insignificant or undesirable. Taxes such as import duties on raw materials and capital goods were very low to begin with. Additional reductions had no effect on private location decisions and may thus have resulted in unnecessary losses of public revenues.

In Thailand, the Board of Investment tried to increase the growth rate of regions outside Bangkok in the 1970s and 1980s by offering tax holidays to new firms. The incentives did not result in a large shift of investment from Bangkok to regional cities. Their failure to do so can be attributed partly to problems with the design of the incentive program, which was in the form of deductions from taxable profits (World Bank 1980). Producers in regional cities faced persistent cost disadvantages, significantly reducing the profitability of new firms. Initial tax holidays were not a sufficient inducement. Moreover, eligibility criteria based on a minimum size cut-off (defined in terms of minimum capital investment, capital 
assets, or production capacity) made most small-scale and agro-based local firms ineligible for incentives.

In each of these countries, fiscal incentives were used to try to divert growth from major agglomerations to smaller cities and lagging regions. In general, the programs were not adequate to offset gains from agglomeration economies and induce firms to start up or move to smaller urban centers. It is possible that policies that seek to redirect investment from major agglomerations to more comparable areas may alter location decisions at the margin.

Reviewing the literature on taxation and local economic development, Wasylenko and others (1997) show that firms are more sensitive to tax rates when comparing location choices within a metropolitan region (core or suburb) than when comparing locations across regions. Various studies based on U.S. data show that the smaller the area over which a firm is considering a location, the more similar are nontax factors across subareas. Within the metropolitan-wide labor market, for example, the same labor force would be available in all areas being considered, and other factor costs would be about the same. At the margin, tax rates or incentives thus become more significant. Studies using interregional or interstate data for the United States show that the average elasticity for the tax responsiveness of firm location and economic growth is - 0.3 (Bartik 1994). In contrast, intraregional studies show much higher responsiveness of firm location decisions and employment to variations in tax rates, with elasticities of about - 1.5 (Bartik 1991). Lall and Mengistae (2005) show that differences in the availability of credit and local land registration taxes across India's 40 main cities affected the location decisions of manufacturing firms in India. They estimate elasticities between -0.3 and -0.5 for the responsiveness of firm location to land registration taxes.

This evidence suggests that fiscal incentives have at best modest effects on location decisions across regions, particularly when the choice is between large agglomerations and small peripheral cities or lagging regions. In contrast, fiscal polices do appear to influence business location decisions among comparable locations. The effectiveness of fiscal policies among comparable locations may encourage fiscal competition in which each local jurisdiction tries to attract businesses by undercutting tax rates relative to its neighbors. A potential consequence of this type of fiscal competition is that competing regions may not see any changes to their economic base but will experience significant revenue reductions. For instance, tax rate wars have reduced taxation levels in the southern Indian states of Kerala, Karnataka, and Tamil Nadu. This may result in a negative-sum game between regions and inefficiently low tax rates, preventing public goods from being funded at sufficiently high levels (Rao and Vallaincourt 1994). 


\section{Micro-evidence on Urbanization and Industrialization}

Micro-data from two large developing countries, India and Indonesia, provide evidence on how industrialization influences the urban hierarchy. The data for each country come from national production censuses that classify establishments by sector and location and report a number of economic variables describing the activity of each establishment. Despite differences in data and context between the two countries, a remarkably similar pattern of findings emerges.

Although Indonesia's population (about 221 million in 2005) is about onefifth that of India's (about 1.1 billion in 2005), both are large developing countries with substantial modern sectors. India was relatively industrialized in 1960 but pursued inward-looking policies of state-led industrialization and central planning until the mid-1980s. This period saw sluggish growth and little change in the ratio of manufacturing to GDP. Following internal reform in 1985 and trade liberalization in 1991, economic growth began to accelerate.

Development of a modern manufacturing sector in Indonesia was held back in the 1970s and early 1980s by government regulations and trade restrictions. Significant export activity was limited to natural resources and agricultural products. Deregulation, privatization, and trade reform since the mid-1980s promoted a broader-based, competitive manufacturing sector and led to the emergence of new export industries. This trend accelerated with the end of the Suharto government in 1998. These reforms led to significant increases in per capita incomes, which rose 70 percent between 1985 and 1997.

Indonesia's geography as an island archipelago has historically hindered domestic trade and regional integration. Its urban hierarchy is dominated by Jakarta, where government functions and most domestic and international investment are concentrated. Highly centralized government structures have only recently given way to more decentralized decision-making power by state and local governments.

India, in contrast, has vast interior regions and a number of competing major agglomerations, such as Delhi, Kolkata, Mumbai, Chennai, Hyderabad, and Bangalore. India's federal structure and large geographic size perhaps allow for greater variation in policies and institutions (an example is labor regulation). Despite these differences industrialization has been accompanied by similar changes in the distribution of modern sector activity within the urban hierarchy in the two countries.

\section{Micro-evidence from India}

India's Annual Survey of Industries (MOSPI various years) provides comparable data for 1989-90 and 1996-97. Several trends emerge from these data. Not surprisingly, manufacturing is concentrated in the largest metropolitan areas. 
The 386 Indian districts in the 1990s are grouped into five types: metropolitan centers, peri-metropolitan areas, secondary cites, tertiary cites, and towns and rural areas (table 2). In 1989 the share of manufacturing was larger than the share of population in metropolitan and peri-metropolitan areas and smaller than the share of population in all other areas, including secondary cities. Despite this bias toward metropolitan areas, in absolute magnitude most manufacturing in India was undertaken in small towns and rural areas.

Between 1989-90 and 1996-97 the largest increases in manufacturing activity were in secondary cities, where the share of manufacturing doubled, and in peri-metropolitan areas. This indicates some deconcentration of activity, albeit not to small towns and rural areas, which saw large declines in their shares of manufacturing. Despite this pattern of modest decentralization, metropolitan areas retained their dominance in rapidly growing industrial sectors.

Regression analysis provides additional insights into changes in manufacturing. For each district type, the share of employment in each industry relative to the share of employment in that industry for India as a whole is regressed on a number of industry characteristics (table 3). The results suggest that skillintensive industries are significantly overrepresented in metropolitan and peri-metropolitan districts and underrepresented in tertiary cities, towns, and rural areas. High-productivity sectors are overrepresented in metropolitan areas, capital-intensive sectors are overrepresented in secondary cities, and sectors with large average plant size are overrepresented in peri-metropolitan areas. These results indicate that although there has been some decentralization of manufacturing to peri-metropolitan districts and secondary cities in India, metropolitan areas remain dominant in higher-skill and higher-productivity sectors.

\begin{tabular}{|c|c|c|c|c|c|}
\hline \multirow[b]{2}{*}{ Location type } & \multirow[b]{2}{*}{ Number } & \multicolumn{2}{|c|}{ Population } & \multicolumn{2}{|c|}{$\begin{array}{c}\text { Share of manufacturing } \\
\text { employment }\end{array}$} \\
\hline & & $\begin{array}{l}\text { Total (1991) } \\
\quad(\text { millions })\end{array}$ & $\begin{array}{l}\text { Share of total } \\
\text { (percent) }\end{array}$ & $\begin{array}{c}1989 \\
\text { (percent) }\end{array}$ & $\begin{array}{c}1996 \\
\text { (percent) }\end{array}$ \\
\hline Metropolitan center & 7 & 40.4 & 5.1 & 15.7 & 13.5 \\
\hline $\begin{array}{l}\text { Peri-metropolitan } \\
\text { area }\end{array}$ & 7 & 21.7 & 2.7 & 3.9 & 8.3 \\
\hline Secondary city & 32 & 100.2 & 12.6 & 10.4 & 21.1 \\
\hline Tertiary city & 36 & 86.5 & 10.9 & 7.5 & 10.2 \\
\hline Town or rural area & 306 & 549.2 & 68.8 & 62.4 & 46.9 \\
\hline
\end{tabular}

Source: Population data are from the 1991 Indian Census; manufacturing employment data are from MOSPI various years. 
Table 3. Location of Industries in India by Feature

\begin{tabular}{lccccc}
\hline Item & Metropolitan center & Peri-metropolitan area & Secondary city & Tertiary city & Town or rural area \\
\hline Industry growth & -0.004 & 0.009 & 0.017 & -0.01 & -0.012 \\
Skill intensity & $0.160^{* *}$ & $0.058^{* *}$ & 0.000 & $-0.068^{* *}$ & $-0.151^{* *}$ \\
Capital intensity & $-0.041^{* *}$ & 0.001 & $0.019^{* *}$ & 0.006 & 0.015 \\
Productivity & $0.024^{* *}$ & -0.005 & -0.012 & -0.005 & -0.001 \\
Plant size & 0.008 & $0.013^{* *}$ & -0.007 & $-0.009^{* *}$ & -0.005 \\
$R^{2}$ & 0.11 & 0.07 & 0.01 & 0.10 & 0.03 \\
\hline
\end{tabular}

Dependent variable: Share of industry $i$ in district type relative to share of industry $i$ in India as a whole

** Significant at the 5 percent level.

Note: Factory data are aggregated to the industry level for each district type. Regressions are run separately for each district type. Data are pooled industry cross-sections for 1989-90 and 1996-97. Industry growth is the employment growth rate; skill intensity is the ratio of nonproduction to production worker employment; capital intensity is the ratio of fixed capital to employment; productivity is output per employee; plant size is employment per factory. Number of observations is 346 .

Source: Authors' analysis based on data from the Annual Survey of Industries (MOSPI various years).

Comparison of Greater Mumbai and the peri-metropolitan area of Thane, about 30 kilometers away, provides an interesting case study of metropolitan decentralization in India. Between 1990 and 1997 total manufacturing employment declined 5.2 percent in Greater Mumbai and rose 34.1 percent in Thane. On average more skill-intensive industries-including manufacture of computers and computer-based systems (SIC 367) and electronic valves and tubes and other electronic components (SIC 368) - saw more rapid rates of employment growth in Greater Mumbai (figure 4). Labor-intensive industries with rapid rates of decline included grain milling (SIC 204) and manufacture of made-up textile articles except apparel (SIC 267). Wide variation remains, however, across industries of a given skill intensity.

Very few industries that saw employment growth in Greater Mumbai did not also see employment growth in Thane (figure 5). Some industries-manufacture of electric fans and electric/electrothermic domestic appliances (SIC 364) and industrial machinery for industries other than food or textiles (SIC 354), for example-saw rapid employment growth in both districts. These industries may have experienced systematic employment growth across districts, but there may also have been employment spillovers between the urban center and its surrounding peri-metropolitan area.

Some labor-intensive industries-including spinning, weaving, and processing of synthetic textile fibers (SIC 247) and slaughtering, preparation, and preservation of meat (SIC 200)-declined in greater Mumbai but saw employment growth in Thane. This pattern is consistent with the notion that labor-intensive 
Figure 4. Changes in Employment and Skill Intensity by Standard Industrial Classification level in Greater Mumbai, 1990-97

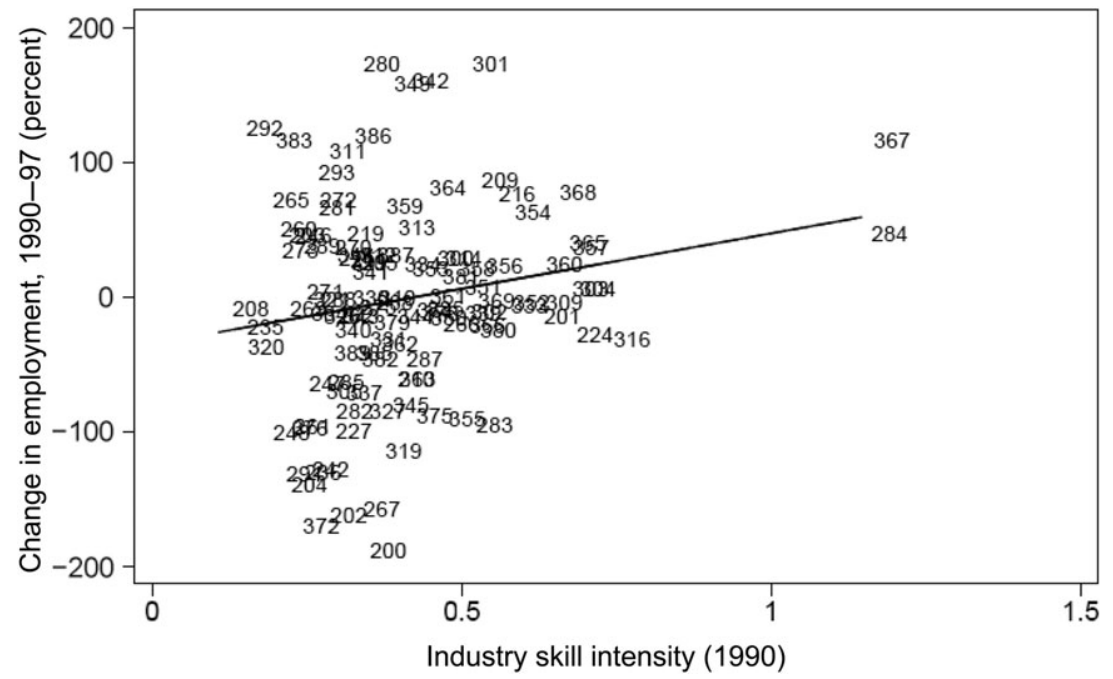

Note: Factory data are aggregated to the district-industry level by Standard Industrial Classification codes [http://exim.inidamart.com/sic-codes/]. Skill intensity is the ratio of nonproduction to production worker employment.

Source: MOSPI (various years).

Figure 5. Changes in Employment by Standard Industrial Classification level in Greater Mumbai and Peri-Urban Thane, 1990-97

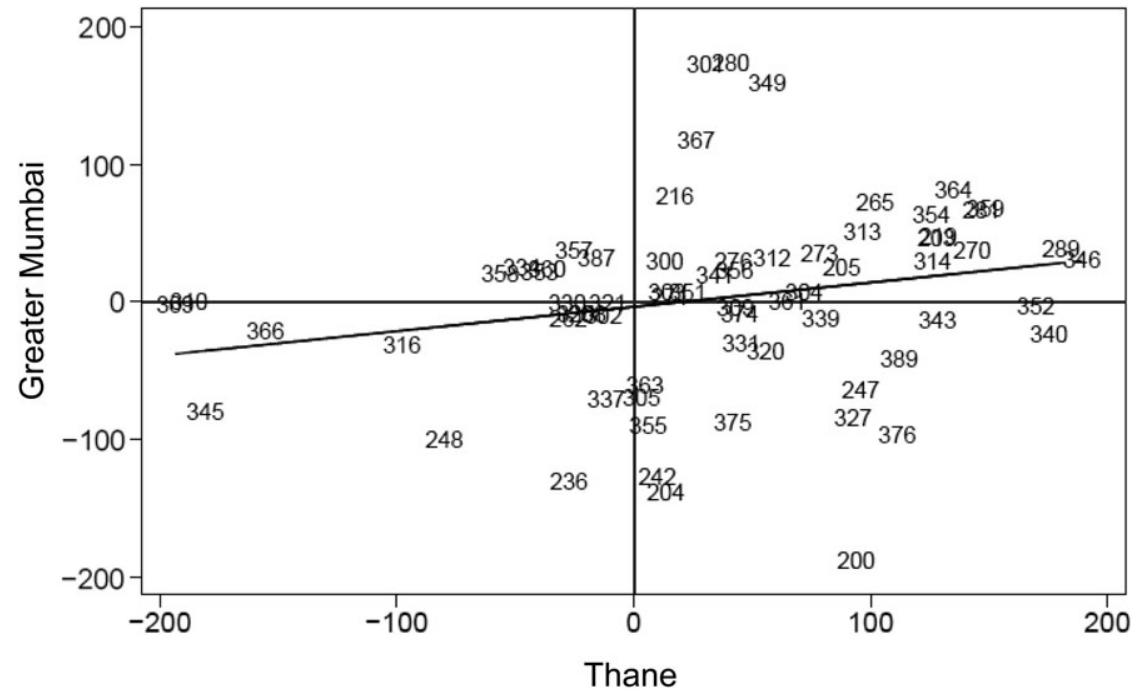

Note: Factory data are aggregated to the district-industry level.

Source: MOSPI (various years). 
industries migrate out of the high-cost urban center to the lower-cost surrounding peri-metropolitan area.

\section{Micro-evidence from Indonesia}

Annual Indonesian industrial census data provide information on the geographic distribution of establishments with at least 20 employees between 1975 and 2001 (BPS various years). The units of analysis are the approximately 340 Indonesian districts (urban kotas and more-rural kabupaten).

Urban districts are based on the size of the city they represent; rural districts are based on their location with respect to those cities (table 4). The categories were adjusted somewhat to reflect the geography of Indonesia and the dominance of Jakarta, whose share of the population increased from 2 percent in 1950 to more than 6 percent in 2005. Despite congestion costs and high factor prices, this megacity of more than 13 million people continues to attract new residents and businesses. A separate urban category for the districts surrounding Jakarta (Jabotabek) was created to take account of change of firm location from Jakarta itself to neighboring areas.

Time series data on the share of establishments in each of the 10 geographic groupings indicate that central Jakarta lost ground in the garment sector (SIC 18) beginning in the 1980s (figure 6). From a high of about 25 percent, the share of the garment industry in the core city dropped to about 5 percent by 2000. A similar but less pronounced pattern is seen in other agglomerations and medium-size cities. This outmigration from cities coincided with an increase in the share of establishments in the Jabotabek region and its neighboring areas, probably as a result of the establishment of new rather than relocated firms. The strongest increase was in districts neighboring cities with at least 1 million

\begin{tabular}{ll}
\hline Table 4. Geographic Grouping of Indonesian Districts for Firm Location Analysis \\
\hline Core & \multicolumn{1}{c}{ Periphery } \\
\hline Central Jakarta & Jakarta periphery (Jabotabek) \\
& Districts neighboring Jakarta agglomeration \\
Major agglomeration $(>1 \text { million })^{\text {a }}$ & Districts neighboring major agglomeration \\
Medium-size city $(250,000-1$ million $)$ & Districts neighboring medium-size city \\
Small city $(100,000-250,000)$ & Districts neighboring small city \\
Other & Districts not near a city \\
\hline
\end{tabular}

a'Bandung, Surabaya, Medan, Palembang, Makassar, and Semarang.

Source: Authors' classification. 
Figure 6. Establishment Shares in the Garment Industry
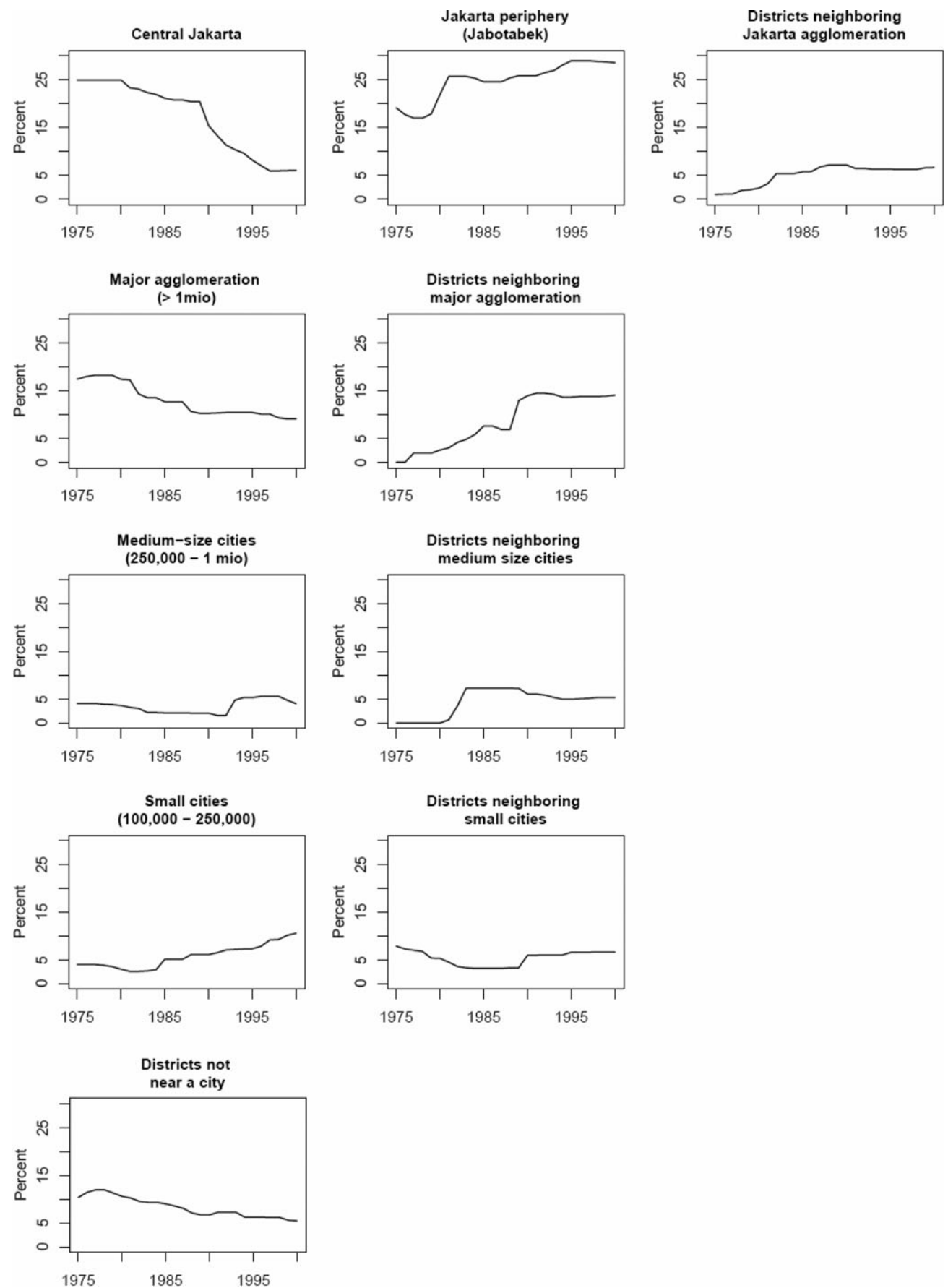

Note: Data include all manufacturing firms in Standard Industrial Classification 18 with 20 or more employees. Source: BPS (various years). 
residents. Similar trends can be found in other large industries, such as chemicals, rubber, and plastics.

More modern sectors, such as machinery and equipment not elsewhere classified (SIC 29), experienced a steep decline in the share of establishments in large agglomerations and an increase in the number of establishments in or near Jabotabek. Electronics and communications equipment and the electrical machinery sector (SIC 31 and 32) show similar trends.

The graphs in figure 6 provide empirical evidence of the trend, identified by Henderson, Kuncoro, and Nasution (1996), showing that many manufacturing firms moved out of Jakarta to the peripheral areas of the Greater Jakarta metropolitan region in the mid-1980s. These moves were facilitated by the construction of toll-ring roads around the city, which allowed firms to retain most of the agglomeration benefits of the region while avoiding the rising production costs associated with congestion and higher land rents. Aggregate transport costs per unit of sales revenue dropped, because a larger market could be accessed by a better road network.

As in India, deconcentration in Indonesia did not lead to development in smaller towns and rural regions. Instead, firms relocated to districts close to major markets and export or transport hubs in order to continue to benefit from agglomeration economies while reducing production costs. Only manufacturing sectors that are closely tied to the natural resource base maintained relatively high establishment shares in the districts neighboring small cities and in districts far from urban centers. These include tobacco (SIC 16); wood products, including furniture (SIC 20 and SIC 36); and, to a lesser extent, food processing (SIC 15).

\section{Conclusion}

Economic growth is strongly associated with modern sector activity and urbanization. While considerable costs are associated with economic production in large urban centers, both the revealed preferences of firms and systematic empirical analysis suggest that the attractions of good market access and other agglomeration economies remain great. As urban centers fill up, firms relocate to the periphery of these centers or to other large cities. Attempts to alter this pattern through fiscal and other incentives have rarely been cost-effective.

For national policymakers, who need to balance the objectives of overall economic efficiency against the need to provide adequate opportunities and quality of life throughout the country, these findings have several implications. First, direct subsidies and tax breaks are costly and rarely lead to a sustainable reorganization of regional economic activities. More promising are spatially blind policies with low opportunity costs, such as streamlining laws and regulations. Investing in 
transportation infrastructure and public services will provide large quality of life benefits for the resident population, even if they fail to attract firms.

Second, strategies that seek to make lagging regions competitive with large cities for high-skill manufacturing industries are unlikely to succeed. Empirical results suggest that firms are likely to relocate from cities into areas near large urban agglomerations rather than to smaller cities elsewhere, because agglomeration benefits continue to compensate for the costs of increasing congestion and higher wages.

There are thus no general recipes for economic development in poorer regions. Policies need to be tailored to develop local specialization in niche industries, in industries that do not require strong agglomeration economies, or in industries that draw on natural advantages linked to agriculture or service sectors.

\section{Notes}

Uwe Deichmann (corresponding author) is a senior environmental specialist in the Development Research Group at the World Bank; his email address is udeichmann@worldbank.org. Somik V. Lall is a senior economist in the Sustainable Development Network at the World Bank; his email address is slall1@worldbank.org. Stephen J. Redding is a reader in economics at the London School of Economics and Political Science and a research fellow at the Centre for Economic Policy Research; his email address is s.j.redding@lse.ac.uk. Anthony J. Venables is a professor of economics at Oxford University; his email address is tony.venables@economics.ox.ac.uk

The authors gratefully acknowledge support from the Department for International Development. They also thank Arunish Chawla, Sabine Kadam, Ralph Ossa, and Asha Sundaram for research assistance; the Statistical Offices of India and Indonesia for providing data access; and Kai Kaiser for valuable comments.

1. The focus here is on firms' ultimate location decisions. Similar econometric methods can be used to analyze intermediate variables that affect firm productivity. The cost of production in a particular industry and its location decisions may depend on similar independent variables, for example. (References to the literature on these effects are made where appropriate in the discussion in the next section.)

2. Henderson, Shalizi, and Venables (2001) note that the deconcentration of industry from the greater São Paulo region in Brazil to lower-wage hinterland cities followed the opening up of major transport corridors, first through São Paulo State and then into Minas Gerais, the interior state with the main iron ore and other mineral and agricultural reserves.

\section{References}

Amiti, M., and L. A. Cameron. 2004. "Economic Geography and Wages." CEPR Discussion Paper 4234. Centre for Economic Policy Research, London.

Amiti, M., and B. S. Javorcik. 2005. "Trade Costs and Location of Foreign Firms in China." Working Paper WP/05/55. International Monetary Fund, Washington, D.C. 
Aschauer, D. A. 1989. "Is Public Expenditure Productive?" Journal of Monetary Economics 23(2): $177-200$.

Bairoch, P. 1988. Cities and Economic Development. Chicago, IL: University of Chicago Press.

Bartik, T. J. 1991. Who Benefits from State and Local Economic Development Policies? Kalamazoo, Mich.: W. P. Upjohn Institute for Economic Research.

1994. "Jobs, Productivity, and Local Economic Development: What Implication Does Economic Research have for the Role of the Government?" National Tax Journal 47(4):847-61.

Besley, T., and R. Burgess. 2004. "Can Labor Market Regulation Hinder Economic Performance? Evidence from India." Quarterly Journal of Economics 119(1):91-134.

Biehl, D. 1986. "The Contribution of Infrastructure to Regional Development." Regional Policy Division, European Communities, Brussels.

Bostic, R. 1997. "Urban Productivity and Factor Growth in the Late 19th Century." Journal of Urban Economics 4(1):38-55.

BPS (Statistics Indonesia). Statistik Industri. Various years. Jakarta: Government of Indonesia.

Burgess, R., and A. J. Venables. 2004. “Towards a Microeconomics of Growth.” In F. Bourguignon, and B. Pleskovic, eds., Accelerating Development: Annual World Bank Conference on Development Economics. Washington, D.C.: World Bank.

Carvalho, A., S. V. Lall, and C. Timmins. 2006. "Regional Subsidies and Industrial Prospects of Lagging Regions.” Policy Research Working Paper 3843. World Bank, Washington, D.C.

Cheng, S. 2007. "Structure of Firm Location Choices: An Examination of Japanese Greenfield Investment in China." Asian Economic Journal 21(1):47-73.

Collier, P. 2007. The Bottom Billion. Oxford: Oxford University Press.

Conrad, K., and H. Seitz. 1992. "The 'Public Capital Hypothesis': The Case of Germany.” Recherches économiques de Louvain 58(3-4):309-27.

Davis, D. R., and D. E. Weinstein. 2003 "Market Access, Economic Geography, and Comparative Advantage: An Empirical Assessment." Journal of International Economics 59(1):1-23.

De la Fuente, A. 2000. "Infrastructures and Productivity: A Survey." Instituto de Analisis Economico, Consejo Superior de Investigaciones Científicas, Madrid.

Deichmann, U., M. Fay, J. Koo, and S. Lall. 2004. "Economic Structure, Productivity, and Infrastructure Quality in Southern Mexico.” Annals of Regional Science 38(3):361-85.

Deichmann, U., K. Kaiser, S. V. Lall, and Z. Shalizi. 2005. "Agglomeration, Transport and Regional Development in Indonesia." Policy Research Working Paper 3477. World Bank, Washington, D.C.

Deno, K. T. 1988. “The Effect of Public Capital on U.S. Manufacturing Activity: 1970 to 1978.” Southern Economic Journal 55(1):400-11.

Devereux, M. P., R. Griffith, and H. Simpson. 2007. "Firm Location Decisions, Regional Grants and Agglomeration Externalities." Journal of Public Economics 91(3-4):413-35.

Dollar, D., G. Iarossi, and T. Mengistae. 2001. "Investment Climate and Economic Performance: Some Firm Level Evidence from India." Paper prepared for the Economists', May 3-4, World Bank, Washington, D.C.

Ferreira, A. H. B. 2000. "Convergence in Brazil: Recent Trends and Long-Run Prospects." Applied Economics 32(4):479-89.

Garcia-Mila, T., and T. McGuire. 1993. "Industrial Mix as a Factor in the Growth and Variability of State's Economies." Regional Science and Urban Economics 23(6):731-48.

Glaeser, E. L., H. D. Kallal, J. A. Scheinkman, and A. Shleifer. 1992. "Growth in Cities." Journal of Political Economy 100(6):1126-52. 
Hanson, Gordon H. 2005. "Market Potential, Increasing Returns and Geographic Concentration." Journal of International Economics 67(1):1-24.

Head, K., and J. Ries. 1996. "Inter-City Competition for Foreign Investment: Static and Dynamic Effects of China's Incentive Areas." Journal of Urban Economics 40(1):38-60.

Henderson, J. V. 2000. The Effects of Urban Concentration on Economic Growth. NBER Working Paper 7503. Cambridge, Mass.: National Bureau of Economic Research.

—. 2002. "Urbanization in Developing Countries." World Bank Research Observer 17(1): 89-112.

Henderson, J. V., A. Kuncoro, and D. Nasution. 1996. "The Dynamics of Jabotabek Development." Bulletin of Indonesian Economic Studies 32(1):71-95.

Henderson, J. V., A. Kuncoro, and M. Turner. 1995. "Industrial Development in Cities.” Journal of Political Economy 103(5):1067-90.

Henderson, J. V., T. Lee, and Y. J. Lee. 2001. "Scale Externalities in Korea." Journal of Urban Economics 49(3):479-504.

Henderson, J. V., Z. Shalizi, and A. Venables. 2001. "Geography and Development." Journal of Economic Geography 1(1):81-105.

Hirschman, A. O. 1958. The Strategy of Economic Development. New Haven, Conn.: Yale University Press.

Lall, S. V., and S. Chakravorty. 2005. "Industrial Location and Spatial Inequality: Theory and Evidence from India." Review of Development Economics 9(1):47-68.

Lall, S. V., and T. Mengistae. 2005. "The Impact of Business Environment and Economic Geography on Plant Level Productivity: An Analysis of Indian Industry." Policy Research Working Paper 3664. World Bank, Washington, D.C.

Lall, S. V., R. Funderburg, and T. Yepes. 2004. "Location, Concentration, and Performance of Economic Activity in Brazil.” Policy Research Working Paper 3268. World Bank, Washington, D.C.

Lall, S. V., H. Selod, and Z. Shalizi. 2006. "Rural-Urban Migration in Developing Countries: A Survey of Theoretical Predictions and Empirical Findings.” Policy Research Working Paper 3915. World Bank, Washington, D.C.

Mani, M., S. Pargal, and M. Huq. 1997. "Is There an Environmental 'Race to the Bottom'? Evidence on the Role of Environmental Regulation in Plant Location Decisions in India." Poverty, Environment and Growth Working Paper 15. World Bank, Washington, D.C.

Mas, M., J. Maudos, F. Perez, and E. Uriel. 1995. "Infrastructures and Productivity in the Spanish Regions." Regional Studies 30(7):641-49.

Mirachy, W. 1995. "Cities and the Product Cycle." Ph.D. diss., Department of Economics, Massachusetts Institute of Technology, Cambridge, Mass.

Morrison, C., and A. E. Schwartz. 1996. "Public Infrastructure, Private Input Demand and Economic Performance in New England Manufacturing." Journal of Business and Economic Statistics 14(1):91-102.

MOSPI (Ministry of Statistics and Program Implementation, India). Various years. Annual Survey of Industries. Delhi: Government of India.

Murray, M. P. 1988. Subsidizing Industrial Location: A Conceptual Framework with Application to Korea. Baltimore, Md.: Johns Hopkins University Press.

Nadiri, M .I. 1970. "Some Approaches to the Theory and Measurement of Total Factor Productivity: A Survey." Journal of Economic Literature 8(4):1137-77. 
Nadiri, M. I., and T. P. Mamuneas. 1994. "The Effects of Public Infrastructure and R\&D Capital on the Cost Structure and Performance of U.S. Manufacturing Industries." Review of Economics and Statistics 76(1):22-37.

Nurske, R. 1953. Problems of Capital Formation in Underdeveloped Countries. London, UK: Basil Blackwell.

Overman, H. G., and A. J. Venables. 2005. "Cities in the Developing World." CEP Discussion Paper dp0695. London School of Economics and Political Science.

Puga, D. 1998. "Urbanization Patterns: European versus Less Developed Countries." Journal of Regional Science 38(2):231-52.

Rao, M. G., and F. Vaillancourt. 1994. "Subnational Tax Disharmony in India: A Comparative Perspective." Working Paper 4/94, National Institute of Public Finance and Policy, Delhi.

Rietveld, P., and J. Boonstra. 1995. "On the Supply of Network Infrastructure: Highways and Railways in European Regions." Annals of Regional Science 29(2):207-20.

Rodrik, D. 2004. "Industrial Policy for the Twenty-First Century." CEPR Discussion Paper 4767, Centre for Economic Policy Research, London.

Rosenstein-Rodan, P. 1943. "The Problem of Industrialization of Eastern and South-Eastern Europe." Economic Journal 53:202-11.

Rud, J. P. 2005. "Coping with an Unfavourably Regulated Monopoly. Evidence from Indian Firms." London School of Economics and Political Science.

Scott, I. 1982. Urban and Spatial Development in Mexico. Baltimore, Md.: Johns Hopkins University Press.

Seitz, H., and G. Licht. 1992. "The Impact of the Provision of Public Infrastructures on Regional Development in Germany.” Discussion Paper 9313, Zentrum für Europäische Wirtschaftsforschung, Mannheim.

Shishido, H., and W. Wheaton. 1982. "Urban Concentration, Agglomeration and Level of Economic Development." Economic Development and Cultural Change 30(1):17-30.

Sveikauskas, L. 1975. "The Productivity of Cities.” Quarterly Journal of Economics 89(3):393-413.

Tabuchi, T. 1986. "Urban Agglomeration, Capital Augmenting Technology, and Labor Market Equilibrium." Journal of Urban Economics 20(1):211-28.

Vernon, R. 1966. "International Investment and International Trade in the Product Cycle." Quarterly Journal of Economics 80(2):180-207.

Wasylenko, M, T. J. Bartik, H. Duncan, T. McGuire, and R. Ady. 1997. "Taxation and Economic Development: The State of the Economic Literature." New England Economic Review March/ April:37-52.

Williamson, J. G. 1965. "Regional Inequality and the Process of National Development." Economic Development and Cultural Change 13(4):3-45.

World Bank. 1977. Spatial Development in Mexico. Report 1081-ME, Washington, D.C.: World Bank. 1980. The Development of Regional Cities in Thailand. Report 2990-TH, Washington, D.C.: World Bank. . 1986. Korea Spatial Strategy Review. Report 5868-KO, Washington, D.C.: World Bank. 1987. Brazil: Industrial Development Issues of the Northeast. Economic and Sector Report. Washington, D.C.: World Bank. . 2004. India: Investment Climate and Manufacturing Industry. Washington, D.C.: World Bank. 2005. World Development Indicators. Washington, D.C.: World Bank. 